\title{
EXPERIMENTAL FLOODS CAUSE ECOSYSTEM REGIME SHIFT IN A REGULATED RIVER
}

\author{
Christopher T. Robinson ${ }^{1}$ AND Urs Uehlinger \\ Department of Aquatic Ecology, EAWAG, 8600 Duebendorf, Switzerland, and Institute of Integrative Biology, \\ ETH Zürich 8092 Switzerland
}

\begin{abstract}
Reservoirs have altered the flow regime of most rivers on the globe. To simulate the natural flow regime, experimental floods are being implemented on regulated rivers throughout the world to improve their ecological integrity. As a large scale disturbance, the long term sequential use of floods provides an excellent empirical approach to examine ecosystem regime shifts in rivers. This study evaluated the long term effects of floods (15 floods over eight years) on a regulated river. We hypothesized that sequential floods over time would cause a regime shift in the ecosystem. The floods resulted in little change in the physicochemistry of the river, although particulate organic carbon and particulate phosphorus were lower after the floods. The floods eliminated moss cover on bed sediments within the first year of flooding and maintained low periphyton biomass and benthic organic matter after the third year of flooding. Organic matter in transport was reduced after the third year of flooding, although peaks were still observed during rain events due to tributary inputs and side slopes. The floods reduced macroinvertebrate richness and biomass after the first year of floods, but density was not reduced until the third year. The individual mass of invertebrates decreased by about one half after the floods. Specific taxa displayed either a loss in abundance, or an increase in abundance, or an increase followed by a loss after the third year. The first three flood years were periods of nonequilibrium with coefficients of variation in all measured parameters increasing two to five times from those before the floods. Coefficients of variation decreased after the third year, although they were still higher than before the floods. Analysis of concordance using Kendall's $W$ confirmed the temporal changes observed in macroinver tebrate assemblage structure. An assessment of individual flood effects showed that later floods had $\sim 30 \%$ less effect on macroinvertebrates than early floods of similar magnitude, suggesting that the new assemblage structure is more resilient to flood disturbance. We conclude that the floods caused an ecosystem regime shift that took three years to unfold. Additional long term changes or shifts are expected as new taxa colonize the river from other sources.
\end{abstract}

Key words: ecosystem regime shift; experimental flooding; flood disturbance, resilience or resistance; macroinvertebrates; river flow regime; temporal scale.

\section{INTRODUCTION}

Flow is arguably one of the most important master variables of river ecosystems (Poff et al. 1997, Hart and Finelli 1999, Malard et al. 2006). Most aquatic organisms have evolved characteristic biological traits adapted to the natural flow regime of free flowing rivers (Lytle and Poff 2004). For example, fishes have specialized morphologies that reflect flow regimes in different types of rivers (Welcomme 1985, Poff and Allan 1995), macroinvertebrates have evolved life history traits adapted to temporary waters (Williams and Hynes 1977, Williams 1996, Stanley et al. 1997), and larger biota such as alligators and turtles have evolved life cycles in rivers that experience an annual flow pulse (Junk et al. 1989, Robinson et al. 2002).

Manuscript received 30 May 2007; revised 31 July 2007; accepted 14 August 2007. Corresponding Editor: C. Nilsson.

${ }^{1}$ E mail: robinson@eawag.ch
Floods are an inherent feature of the natural flow regime of many rivers that impose strong ecological and evolutionary constraints on flowing water organisms (Poff et al. 1997). For instance, floods are important drivers in the relationship of disturbance and produc tivity gradients on biodiversity patterns in rivers (Biggs et al. 1999, Cardinale et al. 2006), and many benthic macroinvertebrates have evolved life cycles to account for predictable seasonal floods such as those associated with spring runoff (Robinson and Minshall 1998). The effects of single flood events, such as reductions in organism densities or standing stocks, on aquatic flora and fauna, whether predictable or unpredictable, have also been well documented (Resh et al. 1988, Boulton et al. 1992, Matthaei et al. 1997, Robinson et al. 2003). In contrast, there is a paucity of information on the ecological and evolutionary influence of experimental floods on river ecosystems (Robinson and Uehlinger 2003). Besides being excellent tests of ecological and evolutionary theory, this kind of information is espe 
cially important with respect to regulated rivers where a paradigm shift has occurred toward incorporating a more natural flow regime in river flow management (Poff et al. 1997, Arthington et al. 2006).

The flows of most rivers of the world are regulated to some extent, with over 45000 large dams (>15 m high) currently in operation and numerous others being built or planned for development (World Commission on Dams 2000, Nilsson et al. 2005). In addition, smaller dams outnumber large ones by orders of magnitude with potential cumulative effects on those streams and rivers (Poff and Hart 2002). The physical and biological effects of dams on downstream receiving waters have been well documented (Ward and Stanford 1979, 1995, Wallace 1990, Vinson 2001, Graf 2006), and recent efforts are beginning to document major impacts to upstream ecosystems as well (Pringle 1997, Greathouse et al. 2006). Many large dams are built to store water for electrical production, often causing reduced and con stant flows in downstream waters with subsequent habitat degradation (Graf 2006). The reduction in disturbance frequency theoretically and empirically results in the loss of biodiversity and a shift toward larger competitively superior taxa (Cardinale et al. 2005, 2006). For example, in a regulated alpine river the benthic macroinvertebrate community was dominated by the large amphipod Gammarus fossarum with densities reaching $>10000$ individuals $/ \mathrm{m}^{2}$ and the major food resource for brown trout (Salmo trutta), the sole fish species in the river (Ortlepp and Mürle 2003, Robinson et al. 2003). Although based on a long history of ecological and evolutionary constructs (e.g., Connell 1978, Huston 1979, Southwood 1988), there is growing recognition that a multivariate habitat template best explains biodiversity patterns of ecosystems (Cardinale et al. 2006), and flowing waters in particular, which should be incorporated into their management.

How ecosystems respond to environmental change such as changes in disturbance regime is a paramount question in ecology today. Current models suggest that ecosystems can respond rapidly to such changes, causing catastrophic regime shifts (Scheffer et al. 2001) or ecosystem switching to an alternative state (Lewonton 1969, Schröder et al. 2005). Three types of regime shifts are recognized and include smooth, abrupt, and discontinuous shifts in response to changes in environ mental conditions through positive feedback mecha nisms (Collie et al. 2004, Suding et al. 2004). The ecological resistance of the ecosystem is a primary controller of the type, if any, of regime shift (Holling 1973, Grunderson 2000). Additional knowledge is needed to accurately assess whether an ecological threshold has been crossed and the mechanisms under lying such behaviors during a regime shift (Suding et al. 2004, Groffman et al. 2006). For instance, recent evidence suggests that ecosystems experience increased variance during the transition between alternative states or regime shift (Carpenter and Brock 2006). Such information is critical for resource managers, as the ecosystem consequences of decisions may be irreversible (Groffman et al. 2006). Most empirical evidence for regime shifts comes from studies on deserts (Kassas 1995), marine ecosystems (Van de Koppel et al. 2001, Knowlton 2004), and shallow lakes (Scheffer et al. 1993), with generally little information on flowing water systems. This type of knowledge is especially important for regulated rivers as changes in environmental conditions will likely result in some form of hysteresis (Scheffer et al. 2001) due to the loss of biodiversity following flow regulation. For example, once in a new state the system may require more than restoration of former environmental conditions to return to the former biotic state.

\section{Study objectives and predictions}

The primary goal of this study was to test whether implementing a novel disturbance regime through experimental floods would cause a regime shift in ecosystem properties of a flow regulated river, where the flow regime has been relatively constant for over 30 years. We predicted that ecosystem properties would change in response to the new habitat template of the river that resulted from a more variable flow regime. We evaluated this prediction by testing different population, community, and ecosystem level hypotheses. We ex pected the floods to have little effect on the physico chemistry of the river because the water source (i.e., hypolimnetic release from the dam) would be the same as before the floods. We hypothesized that the floods would reduce standing stocks of primary producers and eliminate attached moss on bed sediments. The floods should scour bed sediments and dislodge the moss within the first or second year. The pre flood stream bed was highly armored and the floods should reduce armoring and increase the porosity of bed sediments. Although the study river is nutrient rich, the floods should maintain low periphyton biomass by scouring filamentous algae from bed sediments. We hypothesized that the experimental floods would reduce benthic and transported organic matter in the river. Benthic organic matter should decrease because the bed sediments would be mobilized by the floods and benthic particulates would be flushed from the system. Seston (particulate organic matter) levels should decrease because the floods would reduce standing stocks of benthic organic matter and periphyton that are the primary instream sources of seston.

We predicted that the floods would reduce benthic macroinvertebrate density, biomass, and taxon richness, and result in higher proportions of smaller sized organisms. We hypothesized that disturbance prone taxa such as large bodied sessile taxa (e.g., Gammarus fossarum) would decrease in abundance and distur bance resistant taxa such as small bodied, highly mobile taxa (e.g., Baetis sp.) would increase in abundance from the floods. The shift in organism size was expected 
because larger organisms are more associated with taxa that inhabit relatively stable flowing systems, such as before the floods. These taxa should be replaced by more disturbance resistant taxa that tend to be smaller in size.

Lastly, we hypothesized that measured properties would initially become more variable and then less variable as the ecosystem regime shift occurred. The regime shift should be observed by a change in mean values, along with an increase in variation (as coeffi cients of variation, CV) during the shift (Sheffer et al. 2001, Carpenter and Brock 2006). We expected the variation to decrease after the shift, although it would still be higher than before the shift because of the immediate flood effects that cause reductions in organ ism density and biomass. The regime shift would be related to the changes in the composition of benthic macroinvertebrates, as referred to previously. We also predicted that initial floods would have a greater impact than later floods of similar magnitude because of the regime shift in ecosystem properties and changes in macroinvertebrate composition.

\section{Site description and flood program}

The study was conducted on the Spöl River down stream of Livigno reservoir on the Swiss Italian border $\left(10^{\circ} 11^{\prime} 22^{\prime \prime} \mathrm{E}, 46^{\circ} 36^{\prime} 38^{\prime \prime} \mathrm{N}\right)$, lying within the central part of the inner Alps. The climate is continental, with relatively low precipitation and high seasonal variation in temperature (Barry 1992). Terrestrial vegetation is dominated by coniferous forest (Picea excelsa and Pinus mugo), and alder (Alnus incana) is common along the river margin. The river below the dam (Punt dal Gall) flows through a canyon confined valley within the Swiss National Park for $\sim 5.7 \mathrm{~km}$ before entering Ova Spin reservoir. Maximum elevation of the Spöl catchment is $3302 \mathrm{~m}$ above sea level and the study reach was at 1660 m a.s.l. $\sim 2.3 \mathrm{~km}$ downstream of Punt dal Gall. The Spöl eventually flows into the Inn River, a major tributary of the Danube. Before regulation, the Spöl had a typical flow regime dominated by snow melt/glacial melt with high flows in summer and low flows in winter (Fig. 1). Periodic peak flows or floods from heavy rainfall, between $20 \mathrm{~m}^{3} / \mathrm{s}$ and $60 \mathrm{~m}^{3} / \mathrm{s}$, mostly occurred during the summer and into early autumn.

The Spöl is part of a complex hydroelectric scheme (Scheurer and Molinari 2003). Punt dal Gall dam became operational in 1970 and flow regulation resulted in the annual mean discharge in the Spöl to decrease from 8.6 to $1.0 \mathrm{~m}^{3} / \mathrm{s}$. Regulated flows averaged $0.55 \mathrm{~m}^{3} / \mathrm{s}$ in winter and from $1.0 \mathrm{~m}^{3} / \mathrm{s}$ at night to $2.5 \mathrm{~m}^{3} / \mathrm{s}$ during the day in summer using hypolimnetic water from the reservoir (Fig. 1). This residual flow lacked the power to entrain and transport coarse sediments and allowed the riverbed to be clogged with fine sediments, which impaired the natural reproduction of the brown trout population (Ortlepp and Mürle 2003) and enhanced the formation of large pools upstream of lateral debris fans (Mürle et al. 2003). The stable flows also resulted in dense algal mats, extensive moss beds, and an inverte brate community atypical of an alpine mountain river (Robinson et al. 2003).

The power company, the Swiss National Park, and state authorities agreed in 1996 to study the possibility of improving habitat conditions in the river by using experimental floods (Scheurer and Molinari 2003). The floods were cost neutral because of the configuration of reservoirs, aqueducts, and power houses that allowed reallocation of water for power production while maintaining residual flows in the Spöl. Residual flows were further reduced $\left(0.55 \mathrm{~m}^{3} / \mathrm{s}\right.$ winter, $1.45 \mathrm{~m}^{3} / \mathrm{s}$ summer) beginning in 1999 to compensate for water released during each flood (Uehlinger et al. 2003). The experimental flood program began in summer 2000, and based on the ecological results to date has been adopted in the regulatory framework of the reservoir ( $\mathrm{P}$. Molinari, personal communication).

Fifteen separate floods were released between 2000 and end of 2006 (Fig. 1). The flood program began with three floods each in 2000 and 2001, then alternating between two floods and a single flood per year since 2002. The three floods in 2000 and 2001 consisted of two smaller flows between $12 \mathrm{~m}^{3} / \mathrm{s}$ and $16 \mathrm{~m}^{3} / \mathrm{s}$ in June and August that bounded a higher flow (42 and $55 \mathrm{~m}^{3} / \mathrm{s}$, respectively) in July. One unplanned flood in October 2000 resulted from heavy precipitation that filled the reservoir above storage capacity and caused a three day release of surplus water that peaked at $28 \mathrm{~m}^{3} / \mathrm{s}$. After 2002, the June flood was eliminated, and a high flow occurred in July with a smaller flow in August (2002: 51.1 and $13.9 \mathrm{~m}^{3} / \mathrm{s} ; 2004: 35.9$ and $28.2 \mathrm{~m}^{3} / \mathrm{s} ; 2006: 41.1$ and $26.4 \mathrm{~m}^{3} / \mathrm{s}$, respectively). Single floods were imple mented in $2003\left(41.5 \mathrm{~m}^{3} / \mathrm{s}\right)$ and $2005\left(11.2 \mathrm{~m}^{3} / \mathrm{s}\right)$. Although floods $<15.0 \mathrm{~m}^{3} / \mathrm{s}$ were found to be morpho logically ineffective after 2001, flood flows still varied in size due to water availability between years (e.g., the small flood in 2005). Most later floods were designed to be between $\sim 30 \mathrm{~m}^{3} / \mathrm{s}$ and $50 \mathrm{~m}^{3} / \mathrm{s}$ (Scheurer and Molinari 2003). Each flood lasted 68 hours with the step like rising and falling limb being constrained by the engineering mechanics of the release valve.

\section{Methods}

A $200 \mathrm{~m}$ long reach $\sim 2.3 \mathrm{~km}$ downstream of the dam was used during the eight years of the study. The study reach was accessed via a national park trail. Discharge was recorded at the gauging station at the dam by the Federal Office of Hydrology and Geology. A tempera ture logger (Minilog, Vemco, Nova Scotia, Canada) was installed at the study site and recorded temperature at 1 $\mathrm{h}$ intervals. The logger was downloaded every 46 months. The study reach was visited 72 times between 1999 and 2006 for collection of samples. Many of these visits were intentionally made 13 days before and 12 days after a particular flood, especially in the first three years of the flood program. The sampling frequency was less in the last four years of the study, although samples 


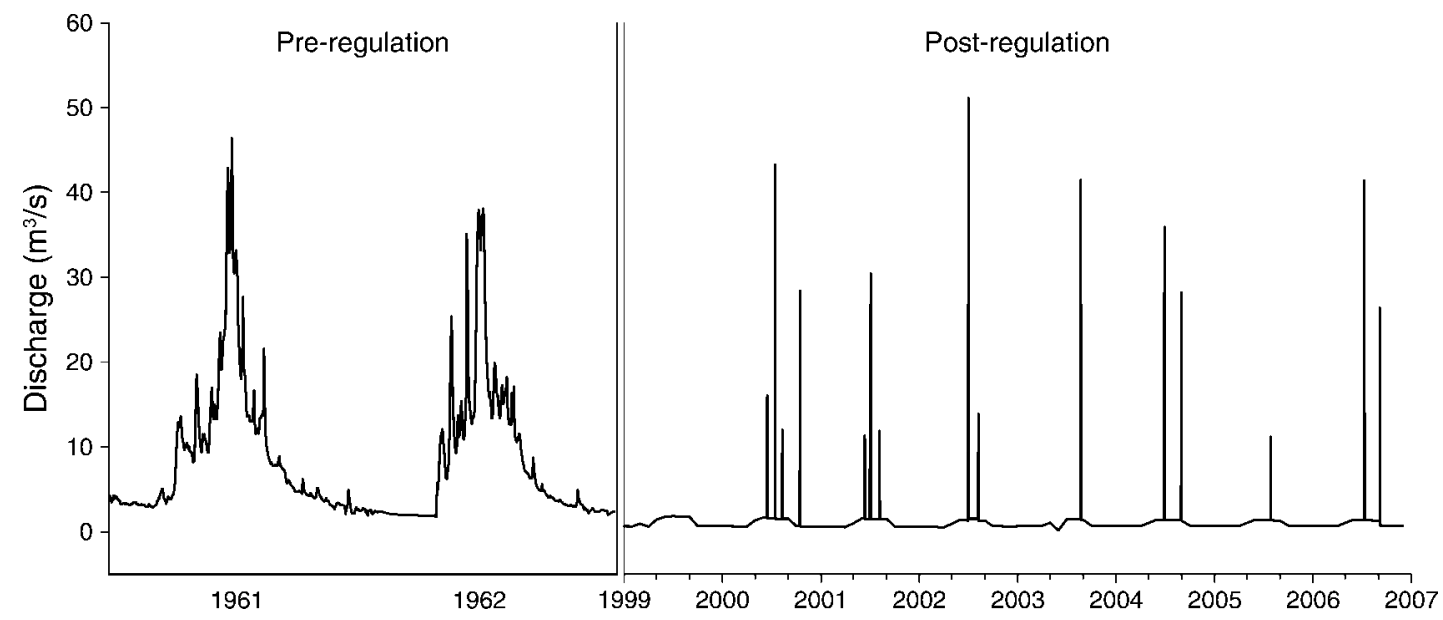

FIG. 1. The flow regime of the Spol River (on the Swiss Italian border) for two representative years before regulation, the year before the flood program (1999) showing the typical seasonal regulated flow, and the flow after the flood program, including each of the experimental floods. Data for 1999 and the years before regulation are daily values. Data are instantaneous values after 2000.

were still collected within five days before and after each flood. On each sampling visit, a $1 \mathrm{~L}$ water sample was collected from the thalweg in a polypropylene bottle for analysis of ammonium $\mathrm{N}$, nitrite $\mathrm{N}$, nitrate $\mathrm{N}$, dissolved and particulate $\mathrm{N}$, soluble reactive $\mathrm{P}$, total dissolved $\mathrm{P}$, particulate $\mathrm{P}$, dissolved organic carbon, and particulate organic carbon following methods detailed in Tockner et al. (1997). In the field, we also measured turbidity (nephelometric turbidity units [NTU]; Cosmos, Züllig $\mathrm{AG}$, Switzerland) and conductivity $\left(\mu \mathrm{S} / \mathrm{cm}\right.$ at $20^{\circ} \mathrm{C}$; WTW LF340, Weilheim, Germany) with portable meters.

Periphyton was measured by collecting 10 rocks (cobble size) randomly within the study reach on each visit. The rocks were placed in plastic bags, returned to the laboratory, frozen at $20^{\circ} \mathrm{C}$, and processed within three weeks after collection. Periphyton was removed from each rock by scrubbing with a wire brush into a bucket with water, and the dimensions ( $a, b$, and $c$ axes) of each rock were measured with a caliper. Aliquots of the periphyton suspension were filtered through glass fiber filters (Whatman $\mathrm{GF} / \mathrm{F}$, pre ashed at $450^{\circ} \mathrm{C}$ ) for determination of chlorophyll $a$ and ash free dry mass (AFDM). Chlorophyll $a$ was determined by HPLC after extraction with hot ethanol (Meyns et al. 1994). AFDM of each sample was determined by drying the filter at $60^{\circ} \mathrm{C}$, weighing, burning the filter at $500^{\circ} \mathrm{C}$ for $4 \mathrm{~h}$, and then reweighing. Area values of chlorophyll $a$ and AFDM were calculated as described in Uehlinger (1991). Prolific growths of moss covered many rocks in the first 23 years of the study and were removed by knife from each rock and biomass estimated as AFDM. Moss data were treated separately from the periphyton data in subsequent analyses.

Replicate seston samples $(N=4)$ were collected on each visit from the thalweg using a $1 \mathrm{~m}$ long net $(100 \mu \mathrm{m}$ mesh, aperture $11 \mathrm{~cm}$ ). Seston refers to the organic matter suspended and transported in the water column, excluding drifting macroinvertebrates. Water flowing through the sampler was measured with a velocity meter (MiniAir II, Schiltknecht, Switzerland) and used to calculate the volume of water filtered. Nets were deployed for $35 \mathrm{~min}$ depending on clogging. Each sample was stored in a Whirl Pak bag (Nasco, Fort Atkinson, Wisconsin, USA), frozen at $20^{\circ} \mathrm{C}$, and processed within three weeks of collection. In the laboratory, each sample was filtered (Whatman GF/F, pre ashed at $450^{\circ} \mathrm{C}$ ), all macroinvertebrates removed from the filter, and the filter then cut in half. One half of the filter was used for chlorophyll $a$ analysis and the other half for AFDM as previously described.

Benthic macroinvertebrates were collected from rif fle/run habitats on each visit $(N=3)$ using a Hess sampler $\left(0.045 \mathrm{~m}^{2}, 250 \mu \mathrm{m}\right.$ mesh). Riffle/run habitats are the most common habitat types in the river because it flows through a canyon confined valley. Samples were stored in plastic bottles and preserved in the field with $70 \%$ ethanol. Macroinvertebrates were hand picked from each sample using a dissecting microscope at $10 \times$ magnification, identified to lowest practical taxonomic unit (usually genus), and counted. The biomass of each taxonomic group in a sample was determined by drying at $60^{\circ} \mathrm{C}$ and weighing. The material remaining in each benthic sample was dried at $60^{\circ} \mathrm{C}$, weighed, burned at $500^{\circ} \mathrm{C}$, and reweighed to obtain estimates of benthic organic matter as AFDM.

\section{Data analysis}

Water chemistry and temperature. We hypothesized that the flood program would not affect the water chemistry or temperature regime in the Spöl River. We tested this hypothesis by comparing values of measured parameters before and after the flood program began using a paired $t$ test (Zar 1984). We also tested this hypothesis by comparing coefficients of variation (CV) 
in measured values before and after the flood program began.

Periphyton, benthic, and transported organic matter. We hypothesized that the floods would eliminate moss coverage and reduce periphyton standing crops and the quantity of seston in the Spöl. We tested this hypothesis using repeated measures ANOVA on log transformed data (Zar 1984). Post hoc testing was done with Tukey's hsd test.

Benthic macroinvertebrates. We hypothesized that macroinvertebrate taxon richness, total density, total biomass, and individual biomass would decrease as a result of the floods. We tested the hypothesis using repeated measures ANOVA on log transformed data (Zar 1984). Post hoc testing was done with Tukey's hsd test. Community level responses were examined further using principal components analysis (PCA) based on the biomass and relative density data of the different taxonomic groups. Data were log transformed (bio mass) or arcsine square root transformed (relative density) prior to running the PCA (varimax rotated).

Eight taxa were sufficiently abundant to test for flood effects on their densities. Three of these taxa were expected to decrease in density based on species traits that suggested poor resistance to flood disturbance: the amphipod Gammarus fossarum, the turbellarian Creno bia alpina, and Trichoptera (mostly Allogamus uncatus and Rhyacophila spp.). Five of these taxa were expected to benefit from the floods because their species traits suggested good resistance or resilience to flood distur bance: the mayfly Baetis spp., the stonefly Protonemura sp., the blackfly Simulium sp., chironomid midges, and a group of various small dipterans (mostly Dicranota sp. and empedids), excluding chironomids. The remaining taxa were grouped as "others" and were expected to decrease in density with floods. Density changes were tested using repeated measures ANOVA on log trans formed data. Post hoc testing was done with Tukey's hsd test.

Regime shift in ecosystem properties. We hypothe sized that ecosystem properties would experience a temporal regime shift with an intermediate period of relative nonequilibrium. Data analyzed included mac roinvertebrate density, biomass, richness, and individual biomass, benthic organic matter, periphyton chlorophyll $a$ and AFDM, and seston chlorophyll $a$ and AFDM. Three periods of time were compared with the analysis: pre flood data, post flood data from 2000 to 2003, and post flood data from 2004 to 2006 . The time periods were selected based on a graphical summary of the different data that suggested a strong transformation period in the system between 2000 and 2003. We tested this hypothesis by comparing changes between time periods using one way ANOVA on log transformed data and coefficients of variation. We further tested the hypothesis using Kendall's $W$ similarity index based on the benthic macroinvertebrate assemblages between sequential years (Zar 1984). Kendall's $W$ is a measure of concordance with values ranging from 0.0 (full concordance) to 1.0 (no concordance). Here we expected communities to initially become dissimilar and then to increase in concordance between years as the regime shift was realized.

Lastly, we tested for an increase in the resistance of the system to flood disturbance by comparing the relative change in invertebrate density and biomass, and periphyton AFDM before and after small $(>10$ $\left.\mathrm{m}^{3} / \mathrm{s}\right)$, intermediate $\left(>25 \mathrm{~m}^{3} / \mathrm{s}\right)$, and large floods $(>40$ $\mathrm{m}^{3} / \mathrm{s}$ ) in 2000 vs. those in 2005 or 2006 . Here we expected the early floods, regardless of size, to cause a greater relative change in examined properties than later floods. All statistical tests were performed using Statistica 6.0 (StatSoft 2001).

\section{RESUltS}

\section{Changes in physical and chemical characteristics}

The change in flow regime caused by the experimental floods resulted in few significant changes in measured physical or chemical parameters of the surface water (Table 1). The initial floods actively scoured lateral debris flows resulting from the encroachment of scree slopes (see Mürle et al. 2003). Mean water temperature ranged between $7^{\circ} \mathrm{C}$ and $8^{\circ} \mathrm{C}$ and remained fairly constant because of the hypolimnetic release from the reservoir. Specific conductance and turbidity also remained the same, although the $\mathrm{CV}$ for turbidity was higher after the floods due to inputs from tributaries during rain events. This was expected as the post flood samples encompassed a longer time period than the pre flood samples and some field samples were collected on rainy days. Constituents of nitrogen slightly decreased after the flood by $\sim 12 \%$ but remained relatively high (e.g., mean nitrate $\mathrm{N}=244 \mu \mathrm{g} / \mathrm{L}$ ). Phosphorus $\mathrm{P}$ and dissolved $\mathrm{P}$ concentrations remained the same after the floods, although particulate $\mathrm{P}$ decreased from 9.0 to 5.1 $\mu \mathrm{g} / \mathrm{L}$ (Table 1). Dissolved organic matter was the same before and after the flood program, but particulate organic matter decreased by about one half from 1.2 $\mathrm{mg} / \mathrm{L}$ before the floods to $0.5 \mathrm{mg} / \mathrm{L}$ after the floods.

\section{Changes in organic matter resources}

Moss covered most stones in the Spöl River before the flood program, with an estimated biomass (mean \pm SD) of $137 \pm 286 \mathrm{~g} \mathrm{AFDM} / \mathrm{m}^{2}$ (Uehlinger et al. 2003). By the third flood in 2000 no moss was observed on stones. The floods reduced the biomass of periphyton in the river (AFDM, $F_{1,67}=19.09, P=0.0001$; chlorophyll $a$, $F_{1,68}=35.55, P=0.0001$; Fig. 2A, B). Periphyton biomass reached maximum values between floods in 2001 and 2003 (e.g., $90 \mathrm{~g} / \mathrm{m}^{2}$ AFDM, $400500 \mathrm{mg} / \mathrm{m}^{2}$ chlorophyll $a$ ), before decreasing to relatively low values after $2004\left(\right.$ mean $=20 \mathrm{~g} / \mathrm{m}^{2}$ AFDM, $27 \mathrm{mg} / \mathrm{m}^{2}$ chlorophyll $a$ ). Average pre flood values in 1999 were $29 \mathrm{~g} / \mathrm{m}^{2}$ AFDM and $65 \mathrm{mg} / \mathrm{m}^{2}$ chlorophyll $a$.

The floods reduced the amount of benthic organic matter in the river $\left(F_{1,64}=2.96, P=0.0001\right.$; Fig. 2C). 
TABLE 1. Comparison of physical and chemical measurements and coefficient of variation $(\mathrm{CV})$ recorded the year before and the years after the flood program began.

\begin{tabular}{|c|c|c|c|c|c|c|}
\hline \multirow[b]{2}{*}{ Measurements } & \multicolumn{2}{|c|}{ Before flood $(N$} & \multicolumn{2}{|c|}{ After flood $(N \quad 63)$} & \multirow[b]{2}{*}{$t$} & \multirow[b]{2}{*}{$P$} \\
\hline & Mean (SD) & $\mathrm{CV}$ & Mean (SD) & $\mathrm{CV}$ & & \\
\hline Temperature $\left({ }^{\circ} \mathrm{C}\right)$ & $7.2(1.1)$ & 15 & $7.8(2.2)$ & 29 & 0.254 & 0.802 \\
\hline Conductivity $\left(\mu \mathrm{S} / \mathrm{cm}\right.$ at $\left.20^{\circ} \mathrm{C}\right)$ & $240(22)$ & 9 & $253(25)$ & 10 & 1.451 & 0.179 \\
\hline Turbidity (NTU) $\dagger$ & $15(10)$ & 67 & $10(13)$ & 127 & 1.250 & 0.244 \\
\hline Nitrate $N(\mu \mathrm{g} / \mathrm{L})$ & $295(63)$ & 22 & $244(39)$ & 16 & 2.339 & 0.043 \\
\hline Dissolved N $(\mu \mathrm{g} / \mathrm{L})$ & $384(54)$ & 14 & $336(70)$ & 21 & 2.679 & 0.020 \\
\hline Particulate $\mathrm{N}(\mu \mathrm{g} / \mathrm{L})$ & $28(7)$ & 26 & $22(12)$ & 54 & 2.101 & 0.053 \\
\hline Phosphorus $\mathrm{P}(\mu \mathrm{g} / \mathrm{L})$ & $<1(<1)$ & 125 & $<1(<1)$ & 115 & 0.109 & 0.916 \\
\hline Dissolved $\mathrm{P}(\mu \mathrm{g} / \mathrm{L})$ & $2.3(2.0)$ & 86 & $3.1(3.3)$ & 108 & 0.856 & 0.412 \\
\hline Particulate $\mathrm{P}(\mu \mathrm{g} / \mathrm{L})$ & $9.0(4.4)$ & 49 & $5.1(5.1)$ & 99 & 2.423 & 0.033 \\
\hline Dissolved organic carbon (mg/L) & $0.78(0.26)$ & 34 & $0.87(0.47)$ & 55 & 0.557 & 0.588 \\
\hline Particulate organic carbon $(\mathrm{mg} / \mathrm{L})$ & $1.2(0.7)$ & 63 & $0.5(0.6)$ & 114 & 3.083 & 0.012 \\
\hline
\end{tabular}

Notes: Values of measured parameters were compared before and after the flood program began using a paired $t$ test (Zar 1984). $P$ values $<0.05$ are significant.

$\dagger \mathrm{NFU}$ nephelometric turbidity units.

Benthic organic matter reached pre flood levels (mean $=$ $16.8 \mathrm{~g} / \mathrm{m}^{2}$ ) between floods in 2002 and 2003 before maintaining lower levels after 2004 (mean $\left.=4.4 \mathrm{~g} / \mathrm{m}^{2}\right)$. Seston levels were reduced by the floods (AFDM, $F_{1,64}=$ 18.27, $P=0.0001$; chlorophyll $a, F_{1,55}=50.62, P=$ 0.0001; Fig. 2D, E). Seston AFDM often reached high levels $\left(>100 \mathrm{mg} / \mathrm{m}^{3}\right)$ between floods probably because of particulate inputs from tributaries and side slopes during rain events (e.g., the high peaks in 2003 and 2006 were a result of intense rains in the valley). Seston chlorophyll $a$, on the other hand, peaked between floods from 2001 to $2003\left(>40 \mathrm{mg} / \mathrm{m}^{3}\right)$ in a similar pattern as periphyton chlorophyll $a$, before maintaining low values after 2004 $\left(\right.$ mean $\left.=6.2 \mathrm{mg} / \mathrm{m}^{3}\right)$.

\section{Changes in macroinvertebrate assemblages}

Community changes. The floods reduced the density $\left(F_{1,70}=8.27, P=0.0001\right)$, biomass $\left(F_{1,70}=5.41, P=\right.$ $0.001)$, taxon richness $\left(F_{1,70}=2.92, P=0.0001\right)$, and individual biomass $\left(F_{1,70}=1.81, P=0.001\right)$ of macroinvertebrates in the river (Fig. 3). Average density decreased from 22700 individuals $/ \mathrm{m}^{2}$ in 1999 to 8800 individuals $/ \mathrm{m}^{2}$ after 2003. Average biomass decreased from $13.7 \mathrm{~g} / \mathrm{m}^{2}$ in 1999 to $3.2 \mathrm{~g} / \mathrm{m}^{2}$ after 2003 , and richness from 12.4 taxa in 1999 to 7.1 taxa after the floods. Individual biomass decreased by about one half from $0.62 \mathrm{mg}$ /individual to $0.37 \mathrm{mg}$ /individual after 2003 (Fig. 2). Macroinvertebrate density typically increased between floods to pre flood values, whereas biomass usually remained below pre flood levels, prob ably in response to individual biomass being lower after the floods. Taxon richness decreased after the first floods in 2000 and remained low throughout the study period.

Results of the principal components analysis (PCA) based on the relative abundances of taxa showed a change in assemblage composition from 1999/2000 to 2001, another change from 2001 to 2002, and a subsequent change following 2002 (Fig. 4A). The first two axes explained $45 \%$ of the variation in the data and were loaded by Baetis spp. and Protonemura sp. along axis 1 and Gammarus fossarum and chironomids along axis 2 . The data suggest that the relative abundances of G. fossarum and chironomids decreased after 2000 and then increased again after 2003, whereas the relative abundances of Baetis spp. and Protonemura sp. increased after the floods, especially after 2002. The PCA results based on the biomass of taxa also showed that assemblage structure changed after the floods (Fig. 4B). Here the first two axes explained $52 \%$ of the variation in the data with axis 1 being loaded by Baetis spp., Leuctra sp., chironomids, and Dicronota sp., and axis 2 by Crenobia alpina, Rhithrogena spp., trichopter ans, and Oligochaeta. The scatterplot shows a major change in structure after 2000 along axis 2 with decreases in those taxa explaining axis 2, and a gradual change in structure between years along axis 1 with increases in biomass for those taxa explaining this axis.

Population changes. The floods reduced the density of Gammarus fossarum in the Spöl $\left(F_{1,70}=4.35, P=\right.$ 0.0001; Fig. 5A). Average density before the floods was 7000 individuals $/ \mathrm{m}^{2}$ and it decreased to 2540 individu $\mathrm{als} / \mathrm{m}^{2}$ after 2003. The floods reduced the average abundance of chironomids from 8340 individuals $/ \mathrm{m}^{2}$ before the floods to 2360 individuals $/ \mathrm{m}^{2}$ after $2003\left(F_{1,70}\right.$ $=5.76, P=0.0001$; Fig. 5B). The density of Baetis spp. increased after the floods with interflood peaks reaching $>6000$ individuals $/ \mathrm{m}^{2}$ compared to the pre flood aver age density of 1160 individuals $/ \mathrm{m}^{2}\left(F_{1,70}=3.41, P=\right.$ 0.0001; Fig. 5C). Protonemura sp. also benefited from the floods with average density increasing from 240 individuals $/ \mathrm{m}^{2}$ in 1999 to 1360 individuals $/ \mathrm{m}^{2}$ after the floods $\left(F_{1,70}=10.75, P=0.0001\right.$; Fig. 5D).

Simulium sp. showed an initial sharp increase in density ( $>8000$ individuals $/ \mathrm{m}^{2}$ ) after the floods followed by a decrease after 2003 to levels observed before the floods $\left(<100\right.$ individuals $/ \mathrm{m}^{2} ; F_{1,70}=3.40, P=0.0001$; Fig. 5E). The floods reduced the density of Crenobia alpina from an average 2180 individuals $/ \mathrm{m}^{2}$ in 1999 to 132 individuals $/ \mathrm{m}^{2}$ after the floods $\left(F_{1,70}=3.34, P=\right.$ 0.0001; Fig. 5F). Trichopterans, mostly represented by 

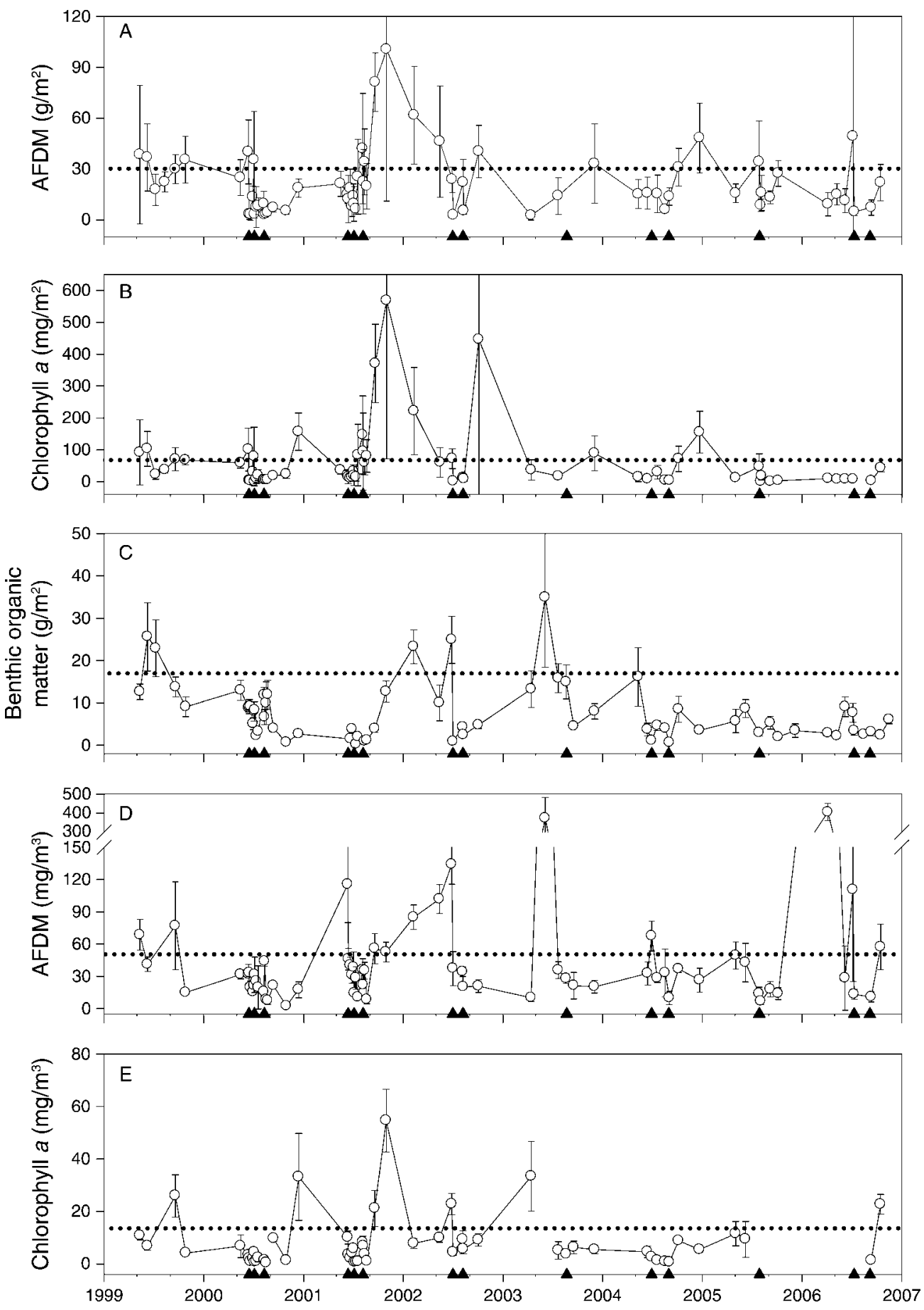

FIG. 2. Temporal changes in periphyton (A) AFDM (ash free dry mass) and (B) chlorophyll $a$ ( $N \quad 10$ for each collection date); (C) temporal changes in benthic organic matter ( $N \quad 3$ per date); and temporal changes in seston (D) AFDM and (E) chlorophyll $a$ ( $N 4$ per date). All values are means \pm SD. Solid triangles along the $x$ axis of each plot show the date of each flood. The dotted line represents the mean value for samples collected the year before the flood program.

Allogamus uncatus and Rhyacophila spp., showed an autumn peak in the pre flood year that was not present after the floods, and densities remained low but relatively constant after the floods $\left(F_{1,70}=7.51, P=\right.$ 0.0001; Fig. 5G). Other Diptera, mostly Dicranota sp. and empedids, showed interflood peaks in density of $>300$ individuals $/ \mathrm{m}^{2}$ that were not evident in 1999 when average density was 100 individuals $/ \mathrm{m}^{2}\left(F_{1,70}=5.74, P=\right.$ 0.0001 ; Fig. $5 \mathrm{H})$. The group labeled as "others" showed an initial increase in density after the floods due to a 

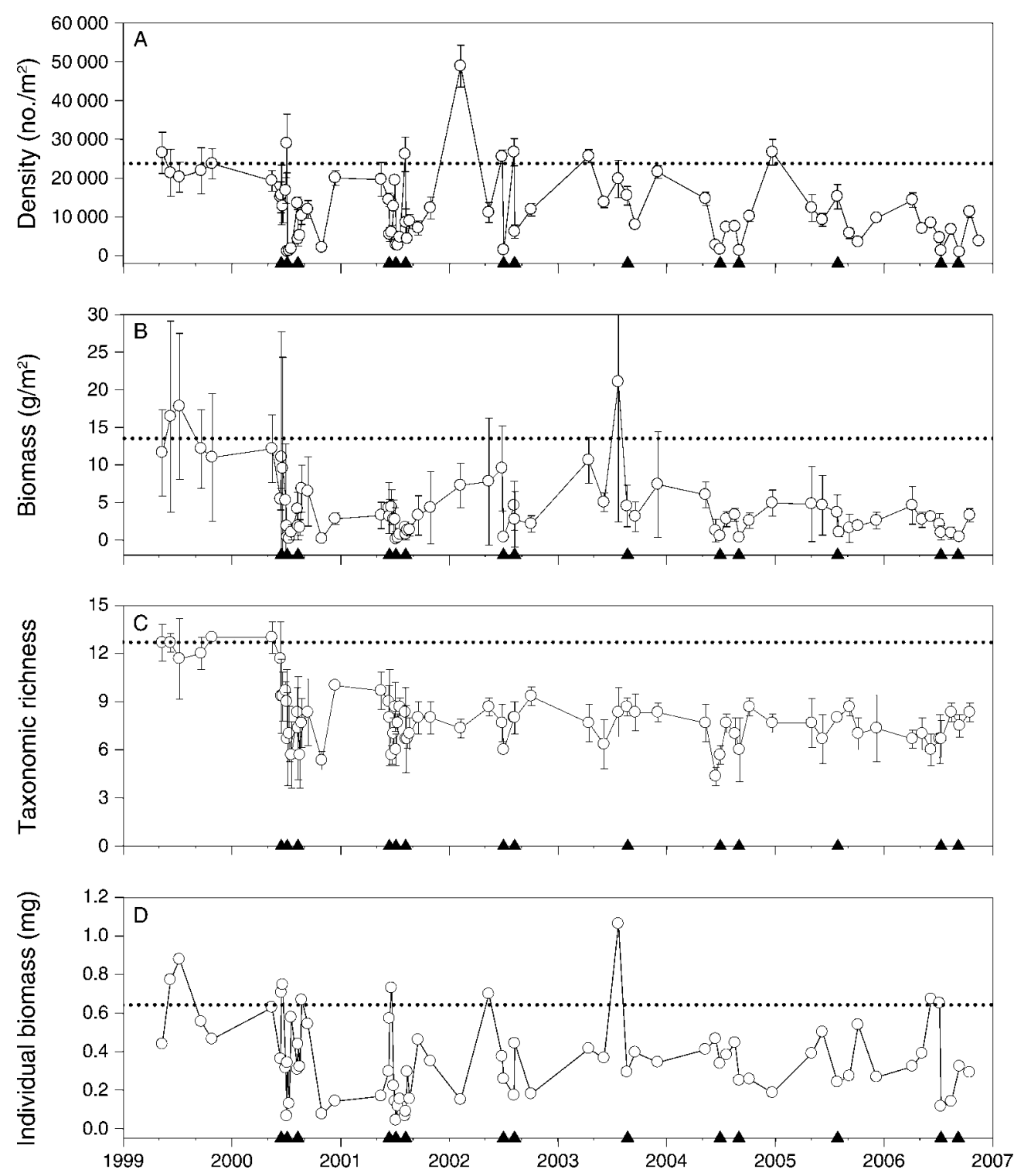

FIG. 3. Temporal changes in macroinvertebrate (A) density, (B) biomass, (C) taxonomic richness, and (D) individual biomass. All values are means $\pm \mathrm{SD} ; N \quad 3$ per date. Solid triangles along the $x$ axis of each plot show the date of each flood. The dotted line represents the mean value of samples collected the year before the flood program.

peak in the density of Leuctra sp. in 20002001 (>6000 individuals $/ \mathrm{m}^{2}$ ), followed by a decrease to an average 40 individuals $/ \mathrm{m}^{2}$ after $2002\left(F_{1,70}=5.74, P=0.0001\right.$; Fig. 5I).

\section{Regime shift in ecosystem properties}

Comparison of ecosystem properties before the flood ("Before") with those between 2000 and 2003 ("Post 1") and those between 2004 and 2006 ("Post 2") showed a decrease in macroinvertebrate density $\left(F_{1,2}=7.77, P=\right.$ $0.001)$, biomass $\left(F_{1,2}=26.09, P=0.0001\right)$, taxon richness $\left(F_{1,2}=41.79, P=0.0001\right)$, and individual biomass $\left(F_{1,2}=\right.$ 5.03, $P=0.007$; Fig. 6A D). Tukey's test showed that Before was higher than Post 1 and Post $2(P<0.05)$, but Post 1 and Post 2 were not different $(P>0.05)$ for these four measures. Comparison also showed that benthic organic matter decreased between periods $\left(F_{1,2}=\right.$ 13.71, $P=0.0001$; Fig. 6E) with Tukey's test indicating that Before was higher than Post 1 and Post $2(P<$ $0.05)$, but Post 1 and Post 2 were not different $(P>$ 0.05). Periphyton biomass also decreased after the floods (chlorophyll $a, F_{1,2}=40.98, P=0.0001$; AFDM, $F_{1,2}=$ 24.48, $P=0.0001$; Fig. $6 \mathrm{~F}, \mathrm{G})$, with Tukey's test indicating Before and Post 1 were higher than Post 2 for chlorophyll $a(P<0.05)$ and Before was higher than Post 1 and Post 2 for AFDM $(P<0.05)$. Seston AFDM did not differ among periods $\left(F_{1,2}=2.65, P=0.072\right)$, whereas seston chlorophyll $a$ decreased after the floods 
FIG. 4. Scatterplot of the results from the principal components analysis based on (A) the relative abundance of taxa and (B) the biomass of taxa. Symbols show means \pm SD of factor scores for samples collected each year of the study along the two primary axes. Taxa labeling each axis had factor loads of 0.70 or higher for that axis.
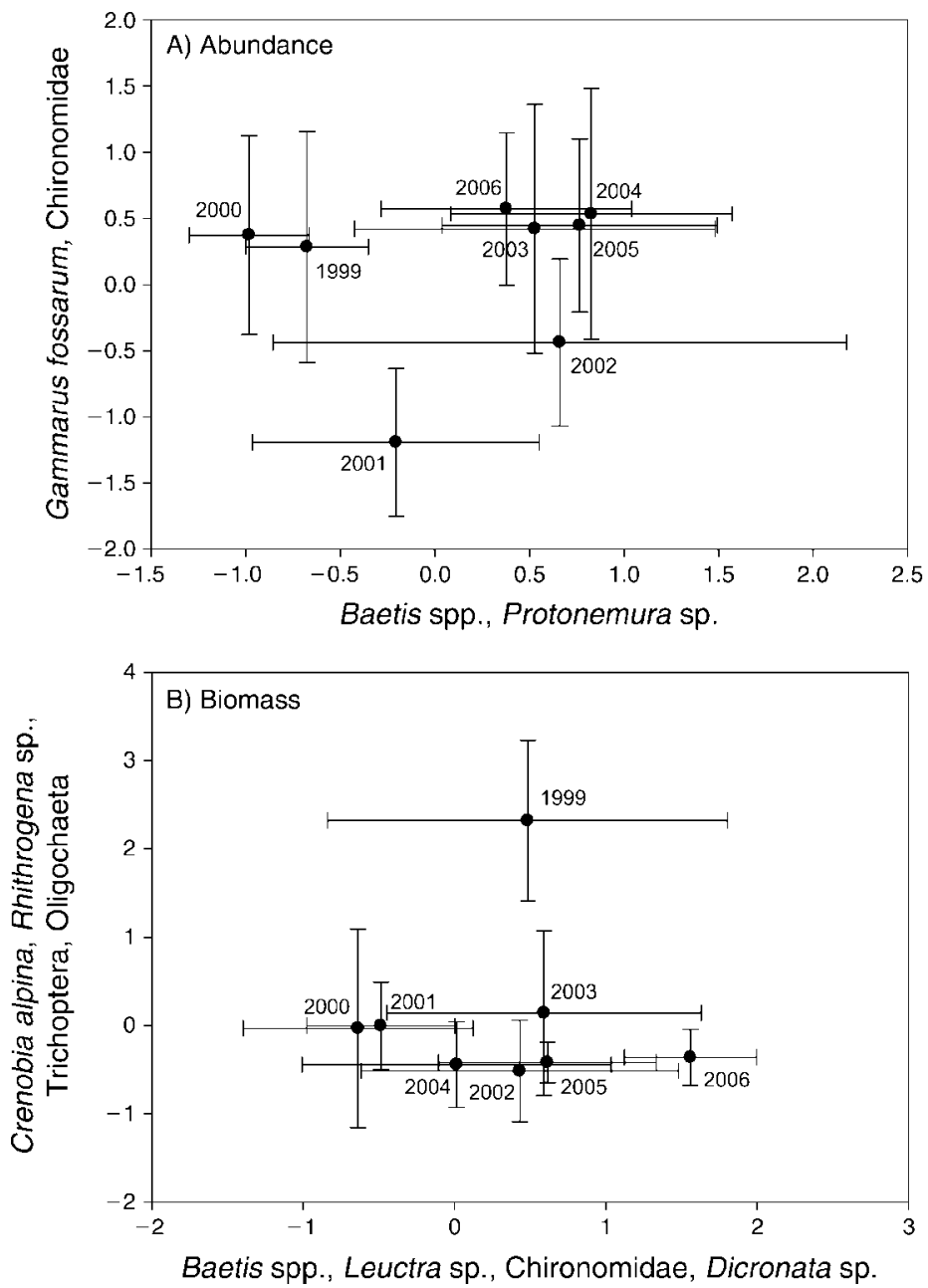

$\left(F_{1,2}=2.97, P=0.05\right.$; Fig. $\left.6 \mathrm{H}, \mathrm{I}\right)$. Tukey's test showed that seston biomass (AFDM and chlorophyll $a$ ) of Post 2 samples was lower than that of Before samples $(P<$ $0.05)$, and Post 1 samples were intermediate to Before and Post $2(P>0.05)$.

In all comparisons, the coefficient of variation $(\mathrm{CV})$ increased two to five times from the Before period to the Post 1 period (Fig. 6A I, solid bars). The CV then decreased for seven of the nine measures from the Post 1 period to Post 2 period. Sample CVs remained similar between Post 1 and Post 2 for macroinvertebrate density and taxon richness. For five of nine measures, the Post 2 sample CV was intermediate to the Before and Post $1 \mathrm{CVs}$. Before and Post $2 \mathrm{CVs}$ were similar for individual biomass and seston chlorophyll $a$.

Kendall's $W$ revealed changes in macroinvertebrate assemblage structure between different years of the study even though taxon richness was relatively low overall. This metric showed a major shift in assemblage structure between 1999 and $2000(W=0.236, P<0.05$; Table 2). The metric then indicated that a similar assemblage structure was present from 2000 through 2002 ( $W=0.001, P>0.05)$, followed by a shift between
2003 and $2004(W=0.063, P<0.05)$. Assemblage structure then was similar between 2004 and 2006 with $W=0.007(P>0.05)$ and $0.015(P>0.05)$, respectively. The percentage change in invertebrate biomass and density after later large floods was lower (usually $>30 \%$ less) than the change from earlier floods (Fig. 7). Small biomass and density regardless of when they occurred. Small later floods $\left(>10 \mathrm{~m}^{3} / \mathrm{s}\right)$ had less of an effect on periphyton AFDM, but large floods $\left(>40 \mathrm{~m}^{3} / \mathrm{s}\right)$ had similar affects on periphyton biomass regardless of when they occurred.

\section{DiscusSION}

\section{Changes in physicochemistry}

We predicted few changes in the physicochemistry of the surface water in the Spöl River because the source of water was the same (i.e., hypolimnetic reservoir water), regardless of the floods. This kind of release maintained water temperatures and nutrient concentrations similar to those before the floods. The most significant physical change was obviously the altered flow regime that floods $\left(>10 \mathrm{~m}^{3} / \mathrm{s}\right)$ had similar low effects on invertebrate 

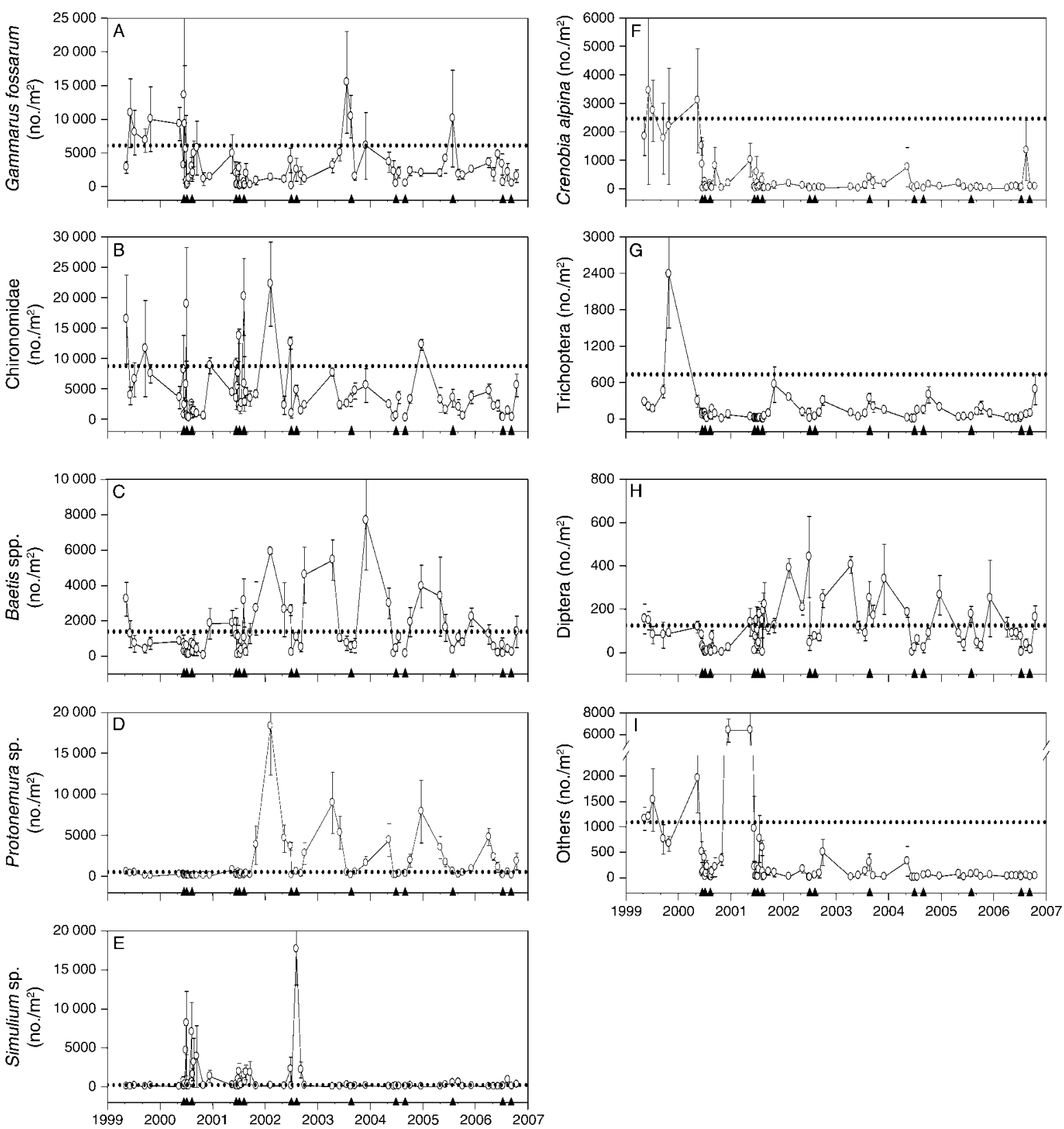

FIG. 5. Temporal changes in density (mean \pm SD) of (A) Gammarus fossarum, (B) Chironomidae, (C) Baetis spp., (D) Protonemura sp., (E) Simulium sp., (F) Crenobia alpina, (G) Trichoptera, (H) Diptera other than chironomids, and (I) all other taxa combined. $N 3$ for each collection date. Solid triangles along the $x$ axis of each plot show the date of each flood. The dotted line represents the mean value of samples collected the year before the flood program.

incorporated floods of various magnitudes (Fig. 1). In contrast to restoring the natural flow regime (sensu Poff et al. 1997), flows between each flood were regulated as before the floods and represented a compromise between economy and ecology (Scheurer and Molinari 2003). For instance, the natural high flows that would occur in summer from glacial melt and rain events were not present during the flood program. The flood peaks during the flood program were similar to flood peaks before regulation, although the duration was shorter because the amount of water available for use during each flood was regulated by the power authorities.

A result of earlier research suggested the smaller floods $\left(1015 \mathrm{~m}^{3} / \mathrm{s}\right)$ that were effective in mobilizing bed sediments in the first year had lost that ability in later years (Mürle et al. 2003). Part of this result was due to the reduction of fine sediments that could be mobilized by small floods. The fine sediments were effectively flushed from the system with the earlier floods and, as a consequence, larger floods were needed later to mobilize 

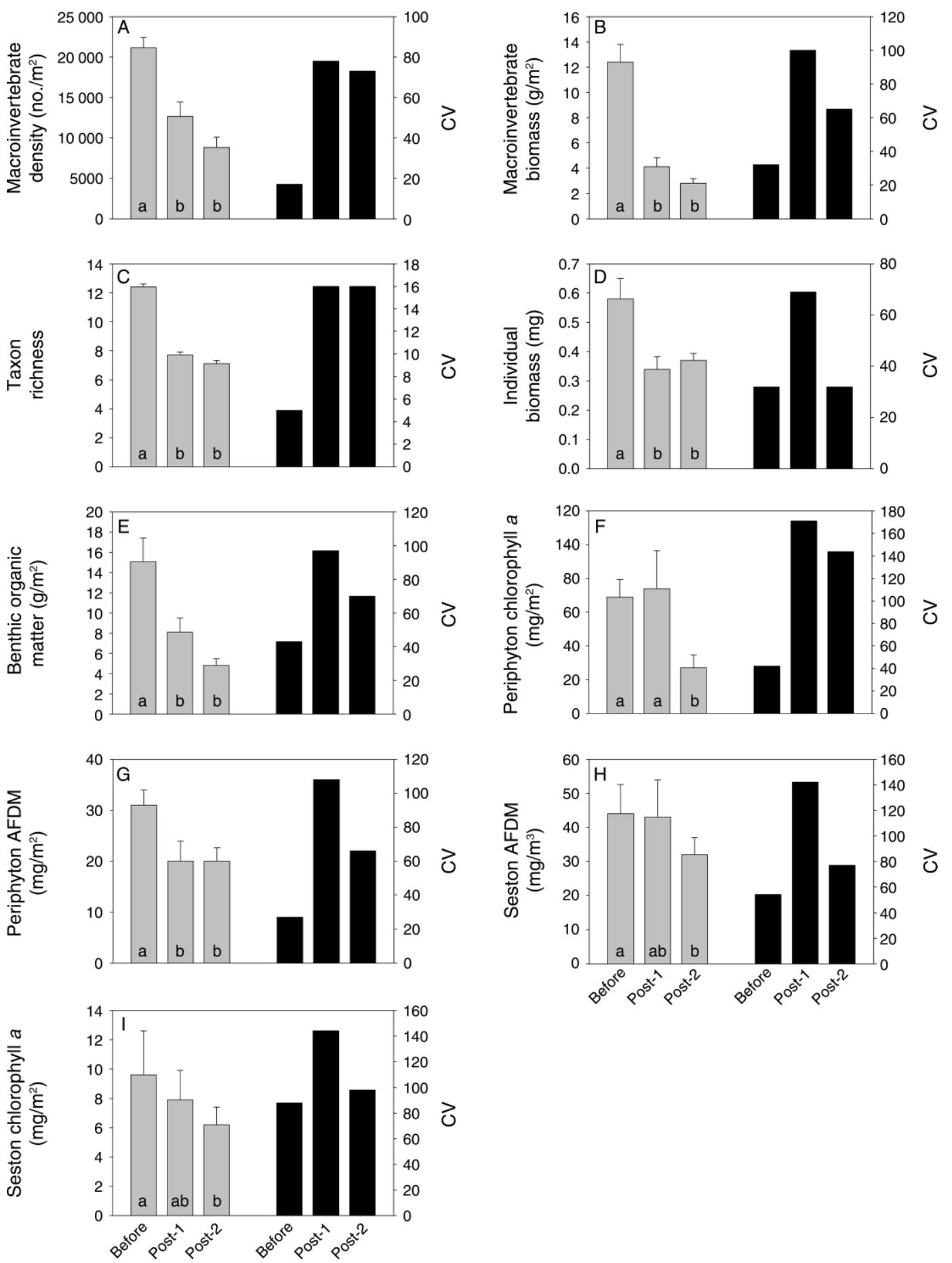

FIG. 6. Gray bars (means + SD) and black bars (coefficients of variation) for samples collected before the floods, samples collected after the first flood in 2000 and until just before the flood in 2003 (Post 1), and samples collected after the flood of 2003 (Post 2). Data are presented for (A) macroinvertebrate density, (B) macroinvertebrate biomass, (C) taxon richness, (D) individual biomass, (E) benthic organic matter, (F) periphyton chlorophyll $a,(\mathrm{G})$ periphyton AFDM, (H) seston AFDM, and (I) seston chlorophyll $a$. Letters within bars indicate significant differences at $P<0.05$ based on Tukey's post hoc test. 
TABLE 2. Results of community similarity analysis between years using Kendall's $W$ based on taxa densities.

\begin{tabular}{ccccccccc}
\hline \hline Year & 1999 & 2000 & 2001 & 2002 & 2003 & 2004 & 2005 & 2006 \\
\hline 1999 & 0.000 & 0.236 & 0.005 & 0.056 & 0.061 & 0.094 & 0.043 & 0.120 \\
2000 & & 0.000 & 0.001 & 0.001 & 0.011 & 0.071 & 0.057 & 0.018 \\
2001 & & & 0.000 & 0.031 & 0.034 & 0.031 & 0.047 & 0.047 \\
2002 & & & & 0.000 & 0.025 & 0.023 & 0.073 & 0.051 \\
2003 & & & & & 0.000 & 0.063 & 0.090 & 0.007 \\
2004 & & & & & & 0.000 & 0.007 & 0.015 \\
2005 & & & & & & & 0.000 & 0.007 \\
2006 & & & & & & & & 0.000
\end{tabular}

Note: Values range from 0.0 to 1.0 , with identical assem blages having values of 0.0 and assemblages that differ completely having values of 1.0 .

the larger sediments that presently dominate the stream bed. The observed decrease in particulate organic matter and particulate $\mathrm{P}$ after the floods may be related to this flushing of fine sediments. A primary management objective of the flood program was to increase the porosity of bed sediments to improve the reproductive potential of the fishery, as the bed was heavily armored before the floods (Uehlinger et al. 2003). This objective was met with a continuous increase in the number of redds being documented each year after the floods (Ortlepp and Mürle 2003). Lastly, scree slopes along the Spöl continuously add larger substrate and minimize any loss in habitat resulting from sediment deficits.

\section{Changes in organic matter resources}

The floods reduced organic matter resources in the river as predicted. The mobilization of bed sediments caused the loss of attached moss within the first year and shifted primary production to that of diatoms and periodic growths of filamentous algae. Algal standing stocks reached extremely high levels $\left(>400 \mathrm{mg} / \mathrm{m}^{2}\right.$ chlorophyll $a$ ) between floods in the second and third year of the program before maintaining levels after 2003 at two times below average levels before the floods. The floods also caused a fourfold decrease in benthic organic matter, but not until after the third year of the flood program. As expected, each individual flood reduced the standing stocks of algae and benthic organic matter, and those short term dynamics have been documented in a number of other studies (Fisher et al. 1982, Grimm and Fisher 1989, Uehlinger et al. 1996). The results of this study indicate that the long term use of multiple annual floods can maintain low organic matter resources in flow regulated rivers. High organic loads in flow regulated rivers facilitate the armoring and clogging of bed sediments and reduce the habitat availability for invertebrates and fish.

The change in organic matter resources is associated with changes in food resource quantity and quality and habitat conditions that ultimately affect and cascade through the aquatic food web and potentially into the adjacent terrestrial landscape. A decrease in food resource quantity can limit organism abundances, and changes in quality and habitat can influence the kinds of organisms present and the life history of those organ isms. For instance, the reduction in gammarid abun dance may be related to the loss of moss habitat in the river that provided refuge from foraging fish and trapped organic particles for food. Rader et al. (2007) also noted the importance of moss as a habitat for particular macroinvertebrates in the flow regulated section of the Colorado River (also see Englund 1991). Last, emerging insects from rivers often subsidize terrestrial organisms such as carabid beetles and spi ders along shorelines (Nakano and Murakami 2001, Paetzhold et al. 2005) and birds and bats that forage along river corridors (Power and Dietrich 2002, Power

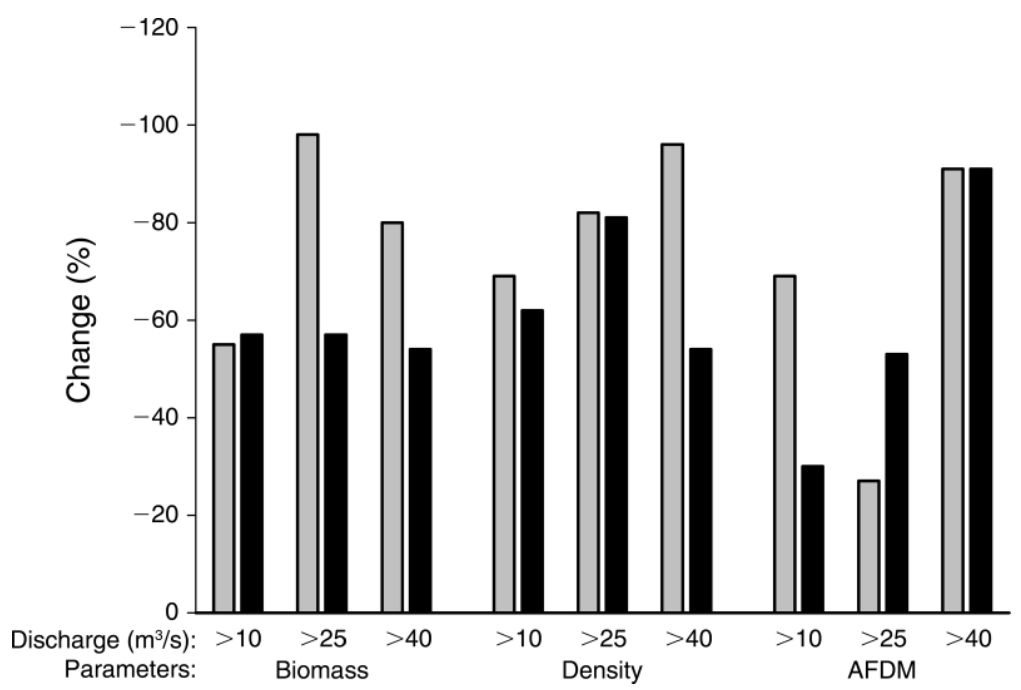

FIG. 7. The percentage change (relative decrease) in invertebrate biomass and density and in periphyton AFDM immediately following floods of different magnitude $\left(>10,>25\right.$, and $\left.>40 \mathrm{~m}^{3} / \mathrm{s}\right)$ in the first and second year (2000 and 2001) of the flood program (gray bars) relative to floods of similar magnitude after 2004 (black bars). 
et al. 2004). Indeed, secondary producers in rivers that emerge as terrestrial adults can significantly influence the abundance and distribution patterns of terrestrial organisms in riparian areas (Nakano and Murakami 2001).

Seston chlorophyll a showed temporal patterns similar to that of periphyton chlorophyll $a$, suggesting that the algal component of seston originated from the sloughing of benthic algae. In contrast, seston AFDM had extremely high values on some collection days that were unrelated to benthic algal standing crops or benthic organic matter. These peaks always occurred on collection days when it rained, suggesting that the seston organic matter was derived from adjacent side slopes and inputs from tributaries. A common effect of dams on downstream waters is the reduction of upstream particulates that are deposited in the reservoir (Ward and Stanford 1979). These data suggest that tributaries could be important sources of particulate organic matter in flow managed rivers, potentially subsidizing organic matter resources in these rivers between floods. This organic matter may contribute to the overall productivity of the system that would otherwise be reduced because of frequent flooding. As such, tributaries can mitigate the energetic losses associated with the reduced organic matter inputs from upstream sources. Tributaries have been found to be important modifiers of ecosystem dynamics in natural flowing waters via inputs of organic matter and drifting invertebrates (Kiffney et al. 2006), and should be considered in management schemes of regulated rivers.

\section{Changes in benthic macroinvertebrates}

The data support our hypothesis of a flood caused reduction in macroinvertebrate richness, biomass, and density. Taxonomic richness decreased by about five taxa in the first year of the flood program and has not subsequently increased. Flow regulation below dams typically results in a loss of biodiversity as the system becomes dominated by a few highly abundant taxa (Vinson 2001). This pattern was evident in the Spöl with large bodied gammarids dominating macroinvertebrate assemblages. Most of the common taxa remained in the system after the floods and the lower richness was due to a loss of less common or rare taxa. Rader et al. (2007) also attributed the lower richness in the years after a major flood in a regulated river to the loss of rare taxa. Single floods typically reduce taxonomic richness in streams immediately following floods with richness quickly recovering to pre flood levels in a matter of weeks (Resh et al. 1988, Robinson et al. 2003). Our results suggest that the long term use of multiple floods can limit the distribution and abundance of some taxa, thereby allowing other taxa to maintain populations even though overall richness values may be reduced. We would expect richness to increase again as more taxa colonize the river from other sources, but this clearly requires a long term multidecadal perspective. The colonization of the river by additional taxa may also be limited by the temperature regime in the river that was unchanged by the flood program. Temperature and its regime can have a major influence on macroinverte brate life histories (Hynes 1970, Vannote and Sweeney 1980).

The floods maintained low macroinvertebrate bio mass and density in the river reach. Biomass decreased fourfold and density threefold, resulting from the sharp decrease in the density of large bodied organisms, gammarids in particular. Indeed, the average individual size of organisms decreased by almost one half after the flood program. The density of organisms recovered quickly between floods, but these were mostly smaller short lived taxa such as baetid mayflies and protone murid stoneflies. Baetids are well known to be highly resilient to disturbance, often being the initial colonizers of denuded substrates (Robinson and Minshall 1986). It remains to be tested whether the decrease in biomass and density translates to lower overall secondary production, or whether the decrease in large bodied organisms was offset by the increase in smaller short lived organisms. Based on literature values (Benke 1984, Robinson and Minshall 1998), annual production: bio mass ratios (P:B ratios) are around 510 for univoltine macroinvertebrates and can be up to 200 for some multivoltine taxa such as chironomids. This order of magnitude difference in population productivity may allow the total productivity of the system to remain at a relatively similar level after the floods to that before the floods. Fish condition has remained the same after the floods (Ortlepp and Mürle 2003), suggesting that food resources are adequate for the fish.

Three different response patterns to the floods were observed, excluding the complete loss of a taxon. The first response was exhibited by the gammarids and the flatworm Crenobia alpina. These taxa decreased in abundance within the first year of flooding and remained at low densities throughout the following study years. The gammarids demonstrated the importance of imple menting multiple floods each year as their numbers increased quickly to pre flood levels in years when only a single flood occurred (i.e., 2003 and 2005). A second type of response was shown by baetid mayflies and protonemurid stoneflies. These taxa were reduced by each flood but recovered quickly between floods. Here baetids recovered rapidly within days to weeks, whereas the protonemurids required weeks to even months to recover. The difference may be related to the mode of dispersal by the two taxa, as baetids are known to drift and protonemurids are active crawlers. Further, the life cycles may differ with baetids showing faster develop ment and perhaps higher reproductive potential than the stonefly. The third response was demonstrated by Simulium blackflies and the stonefly Leuctra sp. These taxa increased in abundance in the first three years of the flood program and then subsequently decreased in abundance to low levels after the third year. These taxa 
also showed low abundances before the floods, suggest ing that they quickly capitalized on the novel habitat conditions early on but failed to maintain high population densities later. The exact mechanism for the decrease in abundance later in the flood program is unknown, but may be related to competitive interactions with other more successful taxa such as baetids and protonemurids. Simulium blackflies have been shown to be poor competitors with other macroinvertebrates such as caddisflies, maintaining populations by quickly recolonizing denuded substrates following disturbance (Hemphill and Cooper 1983). Our data suggest other more complex interactions are occurring over the long term. For example, the flood frequency may be suboptimal for some taxa to sustain large population sizes over the long term; such complex dynamics are missed when examining short term data sets.

\section{Regime shift of ecosystem properties}

Flow regulation below dams often causes an abrupt shift in biotic communities in response to altered habitat conditions resulting from such regulation (Graf 2006). The regulation of flow below dams causes the down stream system to pass an ecological threshold that shifts the ecosystem into a new or alternate state (sensu Scheffer et al. 2001). These alternate states are sustained for years as habitat conditions are maintained by flow regulation, below large dams in particular. Present research also suggests strong upstream effects of dams on stream ecosystems (Greathouse et al. 2006), although the threshold for ecosystem change may be less distinct than that observed for downstream waters. Due to the ecological consequences of flow regulation on stream ecosystems and their functioning, there has been strong emphasis in the last decade towards restoring a more natural flow regime to flow regulated rivers to improve biodiversity (sensu Poff et al. 1997, Arthington et al. 2006). Although economic policies obviously influence how flows are regulated within a particular river (e.g., Poff et al. 2003), how rivers respond over the long term to such changes in flow have been little documented (Robinson and Uehlinger 2003). An overriding question is whether the biodiversity of such rivers will return to pre regulated conditions or will the system enter a stage of hysteresis as observed for other ecosystems such as lakes (Scheffer et al. 2001), oceans (Knowlton 2004), or terrestrial landscapes (Anderson et al. 2000, Suding et al. 2004). The answer has important implications regarding modeling efforts on flow regime changes in different rivers, and the ecosystem consequences of such flow changes.

Our results suggest that the experimental floods caused an ecosystem regime shift in the study reach of the Spöl River. The river ecosystem passed through a three year transition period (i.e., an ecological thresh old) before completely shifting into a new or alternate ecosystem state in year 4 of the flood program. The ecological threshold was measurable as an increase in variance, here as coefficients of variation, in all measured ecosystem parameters during the transition period (Fig. 6). Carpenter and Brock (2006) suggest that an increasing variance is a good indicator of an ecosystem moving through an ecological transition. An important finding from our data is that the transition period lasted for a period of years and was not observed as an easily definable abrupt change. This has important implications for resource managers that may perceive ecological transitions to be abrupt and occur relatively rapidly. A long term perspective is necessary to fully document and understand ecosystem change, especially when drawing conclusions regarding management pol icies. Groffman et al. (2006) conclude that knowledge regarding ecological thresholds is imperative towards understanding and implementing management strate gies.

Although the floods caused the ecosystem to shift into an alternate state, the system appears to still be in a stage of hysteresis (sensu Scheffer et al. 2001). Van Nes and Scheffer (2005) suggest that the temporal length of hysteresis is related to dispersion and the spatial heterogeneity of the system. The inherent high spatial heterogeneity of rivers may be one reason for the delayed multiyear response in ecosystem properties to the new flow regime. Dispersion of control variables such as flood effects on river morphology may be fast in river ecosystems, but ecological responses may be complicated by organism dispersal and colonization abilities. For instance, most changes in macroinverte brate community structure were based on changes in taxa already present in the system. The loss of taxa following flow regulation may impede the recolonization of such taxa following a change in flow regime. Colonization would be dependent on the dispersal ability of taxa from other rivers and streams with viable populations and may take years in a landscape context. The floods clearly benefited more disturbance resistant taxa that typically inhabit rivers with more variable flows, but the loss of taxa influences the degree of reversibility or resilience displayed by the river. Such irreversibility has been documented in a number of ecosystem types and partially explains the lack of a slow recovery following perturbation (e.g., Knowlton 2004, Suding et al. 2004). We expect that a new alternate state will transpire as new taxa colonize the river from other sources, which may take a decade or more to occur.

\section{ACKNOWLEDGMENTS}

We especially thank R. Illi for analysis of all water chemistry and chlorophyll samples, and C. Jolidon for field assistance and the processing of all invertebrate samples. Others who helped in the field on various visits include S. Blaser, M. T. Monaghan, M. Hieber, C. Jakob, S. Aebischer, P. Burgherr, U. Murle, J. Ortlepp, S. Matthaei, D. Tonolla, B. Imhof, R. Vukelic, D. van der Nat, M. Doring, K. Kopp, K. Klappert, and L. N. S. Shama. The Swiss Federal Office for Water and Geology kindly provided the discharge records for the Spol. Partial funding was provided by the Swiss National Park. We thank T. Scheurer and F. Filli of the Swiss National Park for advice and logistic 
support during the study. We thank D. Merritt and an anonymous reviewer for providing constructive comments that improved the manuscript.

\section{Literature Cited}

Anderson, R. C., J. E. Schegman, and M. R. Anderson. 2000. Micro scale restoration: a 25 year history of southern Illinois barrens. Restoration Ecology 8:296 306.

Arthington, A. H., S. E. Bunn, N. L. Poff, and R. J. Naiman. 2006. The challenge of providing environmental flow rules to sustain river ecosystems. Ecological Applications 16:1311 1318.

Barry, R. C. 1992. Mountain weather and climate. Routledge, London, UK.

Benke, A. C. 1984. Secondary production of aquatic insects. Pages 289322 in V. H. Resh and D. M. Rosenberg, editors. The ecology of aquatic insects. Praeger Publishers, New York, New York, USA.

Biggs, B. J. F., N. C. Tuchman, R. L. Lowe, and R. J. Stevenson. 1999. Resource stress alters hydrological distur bance effects in a stream periphyton community. Oikos 85 : 95108.

Boulton, A. J., C. G. Peterson, N. B. Grimm, and S. G. Fisher. 1992. Stability of an aquatic macroinvertebrate community in a multiple hydrologic disturbance regime. Ecology 73:2192 2207.

Cardinale, B. J., H. Hillebrand, and D. F. Charles. 2006. Geographic patterns of diversity in streams are predicted by a multivariate model of disturbance and productivity. Journal of Ecology 94:609 618.

Cardinale, B. J., M. A. Palmer, A. R. Ives, and S. S. Brooks. 2005. Diversity productivity relationships in streams vary as a function of the natural disturbance regime. Ecology 86 : 716726.

Carpenter, S. R., and W. A. Brock. 2006. Rising variance: a leading indicator of ecological transition. Ecology Letters 9: 311318.

Collie, J. S., K. Richardson, and J. H. Steele. 2004. Regime shifts: Can ecological theory illuminate the mechanisms? Progress in Oceanography 60:281 302 .

Connell, J. H. 1978. Diversity in tropical rain forests and coral reefs. Science 199:1302 1310.

Englund, G. 1991. Effects of disturbance on stream moss and invertebrate community structure. Journal of the North American Benthological Society 10:143 153.

Fisher, S. G., L. J. Gray, N. B. Grimm, and D. E. Busch. 1982. Temporal succession in a desert stream ecosystem following flash flooding. Ecological Monographs 52:93 110.

Graf, W. L. 2006. Downstream hydrologic and geomorphic effects of large dams on American rivers. Geomorphology 79: 336360.

Greathouse, E. A., C. M. Pringle, W. H. McDowell, and J. G. Holmquist. 2006. Indirect upstream effects of dams: conse quences of migratory consumer extirpation on Puerto Rico. Ecological Applications 16:339 352.

Grimm, N. B., and S. G. Fisher. 1989. Stability of periphyton and macroinvertebrates to disturbance by flash floods in a desert stream. Journal of the North American Benthological Society 8:293 297.

Groffman, P. M., et al. 2006. Ecological thresholds: the key to successful environmental management or an important concept with no practical application? Ecosystems 9:1 13 .

Grunderson, L. H. 2000. Ecological resilience theory to practice. Annual Review of Ecology and Systematics 31: 421439.

Hart, D. D., and M. Finelli. 1999. Physical biological coupling in streams: the pervasive effects of flow on benthic organisms. Annual Review of Ecology and Systematics 30:363 395.

Hemphill, N., and S. D. Cooper. 1983. The effect of physical disturbance on the relative abundances of 2 filter feeding insects in a small stream. Oecologia 58:378 382.
Holling, C. S. 1973. Resilience and stability of ecological systems. Annual Review of Ecology and Systematics 4:1 23. Huston, M. 1979. A general hypothesis of species diversity. American Naturalist 113:81 101.

Hynes, H. N. B. 1970. The ecology of running waters. University of Toronto Press, Toronto, Ontario, Canada.

Junk, W. J., P. B. Bayley, and R. E. Sparks. 1989. The flood pulse concept in river floodplain systems. Pages 110127 in D. P. Dodge, editor. Proceedings of the Large River Symposium, Canadian Special Publication in Fisheries and Aquatic Science 106.

Kassas, M. 1995. Desertification: a general review. Journal of the Arid Environment 30:115 128.

Kiffney, P. M., C. M. Greene, J. E. Hall, and J. R. Davies. 2006. Tributary streams create spatial discontinuities in habitat, biological productivity, and diversity in mainstem rivers. Canadian Journal of Fisheries and Aquatic Sciences 63:2518 2530.

Knowlton, N. 2004. Multiple 'stable' states and the conserva tion of marine ecosystems. Progress in Oceanography 60: 387396.

Lewonton, R. C. 1969. The meaning of stability. Pages 1324 in Diversity and stability in ecological systems. Brookhaven Symposia in Biology. Number 22. Brookhaven National Laboratory, Brookhaven, New York, USA.

Lytle, D. A., and N. L. Poff. 2004. Adaptation to natural flow regimes. Trends in Ecology and Evolution 19:94 100.

Malard, F., U. Uehlinger, R. Zah, and K. Tockner. 2006. Flood pulse and riverscape dynamics in a braided glacial river. Ecology 87:704 716.

Matthaei, C. D., U. Uehlinger, and A. Frutiger. 1997. Response of benthic invertebrates to natural versus experimental disturbance in a Swiss prealpine river. Freshwater Biology 37:61 77.

Meyns, S., R. Illi, and B. Ribi. 1994. Comparison of chlorophyll $a$ analysis by HPLC and spectrophotometry: Where do the differences come from? Archiv fur Hydro biologie 132:129 139 .

Murle, U., J. Ortlepp, and M. Zahner. 2003. Use of experimental flooding to enhance river integrity below a large dam: sediment processes and changes in geomorphol ogy, habitat structure and riparian vegetation. Aquatic Sciences 65:191 198.

Nakano, S., and M. Murakami. 2001. Reciprocal subsidies: dynamic interdependence between terrestrial and aquatic food webs. Proceedings of the National Academy of Sciences (USA) 98:166 170.

Nilsson, C., C. A. Reidy, M. Dynesius, and C. Revenga. 2005. Fragmentation and flow regulation of the world's large river systems. Science 308:405 408.

Ortlepp, J., and U. Murle. 2003. Effects of experimental flooding on brown trout (Salmo trutta fario). Aquatic Sciences 65:232 238 .

Paetzold, A., C. J. Schubert, and K. Tockner. 2005. Aquatic terrestrial linkages along a braided river: riparian arthropods feeding on aquatic insects. Ecosystems 8:748 759.

Poff, N. L., and J. D. Allan. 1995. Functional organization of stream fish assemblages in relation to hydrological variabil ity. Ecology 76:606 627.

Poff, N. L., J. D. Allan, M. B. Bain, J. R. Karr, K. L. Prestegaard, B. D. Richter, E. E. Sparks, and J. C. Schomberg. 1997. The natural flow regime: a paradigm for river conservation and restoration. BioScience 47:769 784 .

Poff, N. L., J. D. Allan, M. A. Palmer, D. D. Hart, B. D. Richter, A. H. Arthington, K. H. Rogers, J. L. Meyer, and J. A. Stanford. 2003. River flows and water wars: emerging science for environmental decision making. Frontiers in Ecology and the Environment 1:298 306.

Poff, N. L., and D. D. Hart. 2002. How dams vary and why it matters for the emerging science of dam removal. BioScience 52:659 668 . 
Power, M. E., and W. E. Dietrich. 2002. Food webs in river networks. Ecological Research 17:451 471.

Power, M. E., W. E. Rainey, M. S. Parker, J. L. Sabo, A. Smyth, S. Khandwala, J. C. Finlay, F. C. McNeely, K. Marsee, and C. Anderson. 2004. River to watershed subsidies in an old growth conifer forest. Pages 217240 in G. A. Polis, M. E. Power, and G. Huxel, editors. Food webs at the landscape level. University of Chicago Press, Chicago, Illinois, USA.

Pringle, C. M. 1997. Exploring how disturbance is transmitted upstream: going against the flow. Journal of the North American Benthological Society 16:425 438.

Rader, R. B., N. J. Voelz, and J. V. Ward. 2007. Post flood recovery of a macroinvertebrate community in a regulated river: resilience of an anthropogenically altered ecosystem. Restoration Ecology 15:1 10.

Resh, V. H., A. V. Brown, A. P. Covich, M. E. Gurtz, H. W. Li, G. W. Minshall, S. R. Reice, A. L. Sheldon, J. B. Wallace, and R. C. Wissmar. 1988. The role of disturbance in stream ecology. Journal of the North American Benthological Society 7:433 455 .

Robinson, C. T., and G. W. Minshall. 1986. Effects of disturbance frequency on stream benthic community struc ture in relation to canopy cover and season. Journal of the North American Benthological Society 5:237 248.

Robinson, C. T., and G. W. Minshall. 1998. Macroinvertebrate communities, secondary production, and life history patterns in two adjacent streams in Idaho, USA. Archiv fur Hydro biologie 142:257 281 .

Robinson, C. T., K. Tockner, and J. V. Ward. 2002. The fauna of dynamic riverine landscapes. Freshwater Biology 47:661 677.

Robinson, C. T., and U. Uehlinger. 2003. Using artificial floods for restoring river integrity. Aquatic Sciences 65:181 182.

Robinson, C. T., U. Uehlinger, and M. T. Monaghan. 2003. Effects of a multi year experimental flood regime on macroinvertebrates downstream of a reservoir. Aquatic Sciences 65:210 222.

Scheffer, M., S. Carpenter, J. A. Foley, C. Folke, and B. Walker. 2001. Catastrophic shifts in ecosystems. Nature 413: 591596.

Scheffer, M., S. H. Hosper, M. L. Meijer, B. Moss, and E. Jeppesen. 1993. Alternative equilibria in shallow lakes. Trends in Ecology and Evolution 8:275 279.

Scheurer, T., and P. Molinari. 2003. Experimental floods in the River Spol (Swiss National Park): framework, objectives and design. Aquatic Sciences 65:183 190.

Schroder, A., L. Persson, and A. M. de Roos. 2005. Direct experimental evidence for alternative stable states: a review. Oikos 110:3 19.

Southwood, T. R. E. 1988. Tactics, strategies, and templets. Oikos 52:3 18.

Stanley, E. H., S. G. Fisher, and N. B. Grimm. 1997. Ecosystem expansion and contraction in streams. BioScience 47:427 435 .
StatSoft. 2001. STATISTICA (data analysis software system), version 6. StatSoft, Tulsa, Oklahoma, USA. 〈www.statsoft. com $\rangle$

Suding, K. N., K. L. Gross, and G. R. Houseman. 2004. Alternative states and positive feedbacks in restoration ecology. Trends in Ecology and Evolution 19:46 53.

Tockner, K., F. Malard, P. Burgherr, C. T. Robinson, U. Uehlinger, R. Zah, and J. V. Ward. 1997. Characteristics of channel types in a glacial floodplain ecosystem (Val Roseg, Switzerland). Archiv fur Hydrobiologie 140:433 463.

Uehlinger, U. 1991. Spatial and temporal variability of the periphyton biomass in a prealpine river (Necker, Switzer land). Archiv fur Hydrobiologie 123:219 237.

Uehlinger, U., H. Buhrer, and P. Reichert. 1996. Periphyton dynamics in a floodprone prealpine river: evaluation of significant processes by modelling. Freshwater Biology 36: 249263.

Uehlinger, U., B. Kawecka, and C. T. Robinson. 2003. Effects of experimental floods on periphyton and stream metabolism below a high dam in the Swiss Alps (River Spol). Aquatic Sciences 65:199 209.

Van de Koppel, J., P. M. J. Herman, P. Thoolen, and C. H. R. Heip. 2001. Do alternate stable states occur in natural ecosystems? Evidence from a tidal flat. Ecology 82:3449 3461.

Van Nes, E. H., and M. Scheffer. 2005. Implications of spatial heterogeneity for catastrophic regime shifts in ecosystems. Ecology 86:1797 1807.

Vannote, R. L., and B. W. Sweeney. 1980. Geographical analysis of thermal equilibria: a conceptual model for evaluating the effect of natural and modified thermal regimes on aquatic insect communities. American Naturalist 115: 667695.

Vinson, M. R. 2001. Long term dynamics of an invertebrate assemblage downstream of a large dam. Ecological Applica tions 11:711 730 .

Wallace, J. B. 1990. Recovery of lotic macroinvertebrate communities from disturbance. Environmental Management 14:605 620.

Ward, J. V., and J. A. Stanford. 1979. The ecology of regulated streams. Plenum Press, New York, New York, USA.

Ward, J. V., and J. A. Stanford. 1995. The serial discontinuity concept: extending the model to floodplain rivers. Regulated Rivers: Research and Management 10:159 168.

Welcomme, R. L. 1985. River fisheries. Fisheries Technical Paper 262. FAO, Rome, Italy.

Williams, D. D. 1996. Environmental constraints in temporary fresh waters and their consequences for the insect fauna. Journal of the North American Benthological Society 15: 634650 .

Williams, D. D., and H. B. N. Hynes. 1977. The ecology of temporary streams. II. General remarks on temporary streams. International Review of Hydrobiology 62:53 61 .

World Commission on Dams. 2000. Dams and development: a new framework for decision making. Earthscan Publications, London, UK.

Zar, J. H. 1984. Biostatistical analysis. Second edition. Prentice Hall, Englewood Cliffs, New Jersey, USA. 